ARGIPA. 2018. Vol. 3, No. 1: 48-58

Available online: https://journal.uhamka.ac.id/index.php/argipa

p-ISSN 2502-2938; e-ISSN 2579-888X

\title{
ASUPAN KARBOHIDRAT DAN PROTEIN BERHUBUNGAN DENGAN STATUS GIZI ANAK SEKOLAH DI SYAFANA ISLAMIC SCHOOL PRIMARY, TANGERANG SELATAN TAHUN 2017
}

\section{Carbohydrate and Protein Intake Associated With Nutritional Status of Students in Syafana Islamic School Primary, South Tangerang Year 2017}

\section{Muthia Sari ${ }^{1) *}$, Debby Endayani Safitri ${ }^{1)}$, dan Alibbirwin ${ }^{2)}$}

1)Program Studi Gizi; 2)Program Studi Kesehatan Masyarakat, Fakultas Ilmu-ilmu Kesehatan, Universitas Muhammadiyah Prof. DR. Hamka

*E-mail korespondensi: muthiasariparinduri@gmail.com

\section{ABSTRAK}

Status gizi pada anak sekolah dipengaruhi oleh jumlah asupan pangan yang dikonsumsi. Terdapat faktor yang memengaruhi status gizi yaitu faktor langsung (asupan makanan dan penyakit infeksi) dan faktor tidak langsung (ketahanan pangan keluarga, pola pengasuhan anak, lingkungan kesehatan, dan akses pelayanan kesehatan). Penelitian ini bertujuan untuk mengetahui hubungan konsumsi fast food, minuman berkalori, asupan makanan dengan status gizi anak sekolah di Syafana Islamic School yang dilaksanakan pada bulan Oktober-November 2017. Penelitian ini menggunakan penelitian deskriptif dengan desain cross-sectional. Sampel berjumlah 175 orang. Pengambilan sampel dilakukan dengan metode proportional random sampling. Pengambilan data dengan observasi dan wawancara langsung menggunakan kuesioner, FFQ, dan recall $2 \times 24$ jam. Data yang diambil berupa karakteristik siswa (jenis kelamin dan uang saku), konsumsi fast food dan minuman berkalori, asupan makanan (energi dan zat gizi makro), dan status gizi serta menggunakan uji statistik chi-square. Hasil uji statistik chi-square menunjukkan terdapat hubungan antara asupan karbohidrat $(p<0,05)$ dan asupan protein $(p<0,05)$ dengan status gizi. Tidak terdapat hubungan antara konsumsi fast food dan minuman berkalori $(p>0,05)$, asupan energi $(p>0,05)$, dan asupan lemak $(p>0,05)$ dengan status gizi.

Kata kunci: Anak Sekolah, Asupan Makanan, Status Gizi

\section{ABSTRACT}

Nutritional status in elementary student has influenced by the amount of nutrient intake. Many factors are influencing the nutritional status which were direct factors (nutrient intake and infectious diseases) and indirect factors (food safety, childcare patterns, healthty environment, and access to health services). This study aimed to determine the relationship between the consumption of fast food, calorie beverages, and nutrient intake with nutritional status of elementary student in Syafana Islamic School Primary conducted in OctoberNovember 2017. The study design was a cross-sectional with 175 subjects. Places and subjects were selected with proportional random sampling. Data were collected through anthropometric measurements, FFQ, recall $2 \times 24$ hours, and self-administered questionnaire. 
Questionnaires were given to subjects to know of characteristics student (gender and pocket money), fast food consumption, calorie beverages, and nutrient intake (energy and macronutrients), and nutritional status. Data were tested using statistical test chi-square. The result of the chi-square statistic test showed that was relation between carbohydrate intake $(p<0.05)$ and protein intake $(p<0.05)$ with nutritional status. There was no relationship between fast food consumption, calorie beverages $(p>0.05)$, energy intake $(p>0.05)$, and fat intake ( $p>0.05)$ with nutritional status.

Keywords: Student Elementary, Nutritional Status, Nutrient Intake.

\section{PENDAHULUAN}

Perkembangan dan pertumbuhan anak usia sekolah cenderung lebih stabil jika dibandingkan dengan bayi dan balita, namun pada usia sekolah ini anak-anak lebih rentan mengalami masalah gizi. Asupan makanan merupakan salah satu faktor langsung yang memengaruhi asupan zat gizi, bila makanan yang dikonsumsi baik maka status gizi pun akan baik dan sebaliknya (Anzarkusuma, 2014). Perlu perhatian khusus pada jenis makanan yang dikonsumsi oleh anak usia sekolah. Pada masa anak-anak, makanan yang dikonsumsi dipengaruhi oleh multifaktor, salah satunya adalah peranan orangtua terhadap pemilihan makanan (Bryant, 2004), sejalan dengan Virani, et al. (2013) makanan yang biasa dikonsumsi pada masa anak-anak akan membentuk pola kebiasaan makan pada masa selanjutnya.

Masalah gizi yang dapat terjadi bila asupan tidak sesuai dengan kebutuhan adalah gizi kurang dan gizi lebih, World Food Program dan UNESCO (2007) menemukan 60\% anak di dunia mengalami masalah gizi kurang, sedangkan di Indonesia prevalensi gizi kurang berada di 13,9\%
(Riskesdas, 2013). Selain permasalahan gizi kurang, Indonesia juga dihadapkan pada permasalahan gizi lebih. Sebanyak $18,8 \%$ anak usia sekolah di Indonesia mengalami gizi lebih. Sebesar 10,8\% anak usia sekolah masuk dalam kategori gemuk dan $8,8 \%$ masuk ke dalam kategori obesitas (Riskesdas, 2013). Provinsi Banten berdasarkan hasil Riskesdas 2013, termasuk ke dalam 15 provinsi dengan prevalensi sangat gemuk di atas prevalensi nasional.

Peningkatan prevalensi kegemukan pada anak usia sekolah (612 tahun) dikaitkan dengan beberapa faktor antara lain faktor lingkungan yaitu sosial ekonomi keluarga, konsumsi energi yang berlebih, aktivitas fisik, dan paparan iklan mengenai makanan jajanan (Mahan, 2012). Prevalensi gizi kurang yang masih tinggi dikaitkan dengan beberapa faktor seperti kekurangan makanan sumber energi secara umum dan protein bisa mengakibatkan penyakit kurang energi protein (KEP) (Almatsier, 2009). Selain faktor di atas, faktor kesehatan juga berpengaruh terhadap masalah gizi yang meliputi daya beli keluarga, kebiasaan makan, pemeliharaan kesehatan serta 
lingkungan fisik dan sosial (Supariasa, 2001).

Anak sekolah pada saat ini cenderung mengonsumsi fast food dan minuman berkalori yang diketahui keduanya memengaruhi pada status gizi anak sekolah. Peningkatan frekuensi makan fast food dapat meningkatkan Indeks Massa Tubuh (IMT) karena fast food memenuhi sepertiga kebutuhan energi, lemak total, dan lemak jenuh (Bowman dan Vinyard, 2004). Minuman berkalori adalah minuman yang tidak mengandung alkohol, merupakan minuman olahan dalam bentuk bubur atau cair yang mengandung bahan makanan atau bahan tambahan lainnya, baik alami maupun sintetis yang dikemas dalam kemasan siap saji. Mengonsumsi minuman berkalori akan mengurangi konsumsi protein, kalsium, serta vitamin (Edelstein, 2015).

Selain pola konsumsi, hal yang juga memengaruhi status gizi adalah pola aktivitas fisik seperti lamanya berolahraga, kebiasaan menonton televisi, bermain video games, ekstrakurikuler di sekolah, serta lamanya durasi tidur anak sekolah mempunyai pengaruh yang kuat terhadap keseimbangan energi. Beberapa mekanisme fisiologis berperan penting dalam diri individu untuk menyeimbangkan asupan energi dengan energi yang digunakan, untuk menjaga berat badan stabil dalam waktu lama (WHO, 2000).
Tingkat pendidikan ibu merupakan salah satu faktor yang secara tidak langsung dapat memengaruhi status gizi, pendidikan yang tinggi dapat diasumsikan ibu mendapatkan banyak pengetahuan, salah satunya adalah pengetahuan mengenai gizi. Berdasarkan hasil penelitian yang dilakukan oleh Puspasari dan Andriani (2017), pengetahuan ibu berhubungan dengan status gizi anak. Ibu yang memiliki pengetahuan gizi baik mayoritas memiliki anak dengan status gizi normal. Apabila pengetahuan ibu mengenai gizi baik, ibu cenderung akan memerhatikan makanan yang dikonsumsi oleh anak guna memenuhi asupan zat gizi yang seimbang. Selain itu, faktor lain yang tidak langsung yaitu pekerjaan ibu, yang memengaruhi pendapatan keluarga dan besar uang saku pada anak, yang berujung pada kemampuan daya beli anak terhadap jajanan yang akan dikonsumsi.

\section{METODE}

Penelitian ini dilakukan pada bulan Oktober-November 2017 di Syafana Islamic School Primary. Populasi dalam penelitian ini adalah 320 anak sekolah. Sampel pada penelitian ini adalah 175 anak sekolah yang sesuai dengan kriteria inklusi. Pemilihan sampel dilakukan dengan teknik proportional random sampling.

Data yang dikumpulkan pada penelitian ini adalah status gizi, karakteristik anak (jenis kelamin dan 
uang saku), frekuensi konsumsi fast food, frekuensi minuman berkalori, asupan makanan dan gambaran umum Syafana Islamic School Primary. Metode analisis yang digunakan adalah analisis univariat untuk melihat gambaran dan analisis bivariat untuk melihat hubungan antara variabel dependen dengan variabel independen dengan menggunakan software komputer. Data status gizi didapatkan dari hasil pengukuran berat badan dengan menggunakan timbangan injak digital, sedangkan untuk tinggi badan menggunakan microtoise serta untuk perhitungan menggunakan IMT/U dengan rumus Z-score.

Status gizi dikategorikan menjadi gizi lebih dan gizi baik. Data karakteristik anak, karakterisitik ibu, asupan makanan dan aktivitas fisik didapatkan melalui pengisian kuesioner dengan metode wawancara. Data konsumsi fast food dan minuman berkalori didapatkan dengan pengisian kuesioner FFQ yang diisi oleh responden.

\section{HASIL}

Pada penelitian ini jumlah seluruh subjek adalah 175 anak sekolah, dengan $51,4 \%$ subjek berjenis kelamin perempuan dan $48,6 \%$ lakilaki. Untuk variabel uang saku mayoritas subjek $(58,9 \%)$ masuk ke dalam kategori uang saku yang besar. Rata-rata uang saku yang didapatkan oleh subjek sebesar Rp 12.100,00 per hari. Berdasarkan sebaran data konsumsi fast food 85,7\% subjek berada pada kategori sering mengonsumsi fast food. Hal ini disebabkan lingkungan sekolah yang cukup dekat dengan tempat makan fast food.

Jenis fast food yang sering dikonsumsi oleh siswa di Syafana Islamic School makanan yang mengandung energi tinggi, tinggi lemak dan tinggi karbohidrat seperti spaghetti, brownis, dan nasi uduk. Fast food diartikan sebagai makanan tinggi garam dan lemak serta rendah serat (Kemenkes, 2013).

Sebanyak $\quad 67,4 \%$ subjek mengonsumsi minuman berkalori dengan kategori sering. Berdasarkan hasil FFQ, jenis minuman berkalori yang sering dikonsumsi pada penelitian ini yaitu lechy tea, teh kemasan, soft drink. Namun tidak semua subjek dalam penelitian ini mengonsumsi minuman berkalori dikarenakan mendapatkan edukasi dari keluarga subjek.

Hasil wawancara asupan subjek dengan menggunakan food recall 2×24 jam didapatkan hasil rata-rata asupan subjek pada data asupan makan sebanyak $8,0 \%$ subjek memiliki asupan energi lebih; $10,3 \%$ subjek memiliki asupan karbohidrat lebih dan 32,0\% subjek memiliki asupan protein lebih, serta $21,7 \%$ subjek yang memiliki asupan lemak lebih. Diperkirakan ada perbedaan asupan saat hari sekolah dengan hari libur. Pada hari sekolah subjek lebih sering mengonsumsi jajanan dan fast food dibandingkan hari libur. 
Tabel 1.

Distribusi karakteristik siswa, konsumsi fast food, minuman berkalori dan asupan makanan pada anak sekolah

\begin{tabular}{|c|c|c|}
\hline Variabel & $\mathbf{n}$ & $\%$ \\
\hline \multicolumn{3}{|l|}{ Jenis kelamin } \\
\hline Laki-laki & 85 & 48,6 \\
\hline Perempuan & 90 & 51,4 \\
\hline \multicolumn{3}{|l|}{ Uang saku } \\
\hline Kecil & 72 & 41,1 \\
\hline Besar & 103 & 58,9 \\
\hline \multicolumn{3}{|c|}{ Konsumsi fast food } \\
\hline Jarang & 79 & 14,3 \\
\hline Sering & 96 & 85,7 \\
\hline \multicolumn{3}{|c|}{ Minuman berkalori } \\
\hline Jarang & 40 & 22,9 \\
\hline Kadang-kadang & 17 & 9,7 \\
\hline Sering & 118 & 67,4 \\
\hline \multicolumn{3}{|l|}{ Asupan makanan } \\
\hline \multicolumn{3}{|l|}{ Energi } \\
\hline Kurang & 84 & 48,0 \\
\hline Cukup & 73 & 41,7 \\
\hline Lebih & 18 & 10,3 \\
\hline \multicolumn{3}{|l|}{ Karbohidrat } \\
\hline Kurang & 31 & 17,7 \\
\hline Cukup & 88 & 50,3 \\
\hline Lebih & 56 & 32,0 \\
\hline \multicolumn{3}{|l|}{ Protein } \\
\hline Kurang & 31 & 17,7 \\
\hline Cukup & 88 & 50,3 \\
\hline Lebih & 56 & 32,0 \\
\hline \multicolumn{3}{|l|}{ Lemak } \\
\hline Kurang & 66 & 37,7 \\
\hline Cukup & 71 & 40,6 \\
\hline Lebih & 38 & 21,7 \\
\hline \multicolumn{3}{|l|}{ Status Gizi } \\
\hline Sangat kurus & 1 & 0,6 \\
\hline Kurus & 7 & 4,0 \\
\hline Normal & 91 & 52,0 \\
\hline Gemuk & 40 & 22,9 \\
\hline Obesitas & 36 & 20,6 \\
\hline
\end{tabular}

Penentuan status gizi subjek Marfuah (2016), mayoritas anak dilakukan dengan cara pengukuran sekolah memiliki status gizi normal berat badan (BB) dan tinggi badan (68,14\%), sedangkan untuk status gizi (TB). Dari hasil perhitungan tersebut didapatkan proporsi status gizi subjek sangat kurus $(2,20 \%)$ dan obesitas $(5,49 \%)$ cenderung lebih kecil.

sangat kurus $0,6 \%$, kurus $4,0 \%$, normal $52,0 \%$, gemuk 22,9\%, dan obesitas $20,6 \%$. Serupa dengan penelitian yang dilakukan oleh Rahmawati dan 
Tabel 2.

Hubungan konsumsi fast food, minuman berkalori, dan asupan dengan status gizi anak sekolah

\begin{tabular}{|c|c|c|c|c|c|c|c|}
\hline \multirow{3}{*}{ Variabel Independen } & \multicolumn{4}{|c|}{ Status Gizi } & \multirow{2}{*}{\multicolumn{2}{|c|}{ Jumlah }} & \multirow{3}{*}{$p$} \\
\hline & \multicolumn{2}{|c|}{ Gizi lebih } & \multicolumn{2}{|c|}{ Gizi baik } & & & \\
\hline & $\mathbf{n}$ & $\%$ & $\mathbf{n}$ & $\%$ & $\mathbf{n}$ & $\%$ & \\
\hline \multicolumn{8}{|l|}{ Konsumsi Fast Food } \\
\hline Sering & 66 & 44,0 & 84 & 56 & 150 & 100 & \multirow{2}{*}{0,709} \\
\hline Jarang & 10 & 40,0 & 15 & 60 & 25 & 100 & \\
\hline \multicolumn{8}{|l|}{ Minuman Berkalori } \\
\hline Sering & 51 & 43,2 & 67 & 56,8 & 118 & 100 & \multirow{2}{*}{0,936} \\
\hline Jarang & 25 & 43,9 & 32 & 56,1 & 57 & 100 & \\
\hline \multicolumn{8}{|l|}{ Asupan Energi } \\
\hline Lebih & 9 & 64,3 & 5 & 35,7 & 14 & 100 & \multirow{2}{*}{0,101} \\
\hline Cukup & 67 & 41,6 & 94 & 58,4 & 161 & 100 & \\
\hline \multicolumn{8}{|l|}{ Asupan Karbohidrat } \\
\hline Lebih & 27 & 32,1 & 57 & 67,9 & 84 & 100 & \multirow{2}{*}{0,004} \\
\hline Cukup & 49 & 53,8 & 42 & 46,2 & 91 & 100 & \\
\hline \multicolumn{8}{|l|}{ Asupan Protein } \\
\hline Lebih & 7 & 22,6 & 24 & 77,4 & 31 & 100 & \multirow{2}{*}{0,010} \\
\hline Cukup & 69 & 47,9 & 75 & 52,1 & 144 & 100 & \\
\hline \multicolumn{8}{|l|}{ Asupan Lemak } \\
\hline Lebih & 27 & 40,9 & 39 & 59,1 & 66 & 100 & \multirow[b]{2}{*}{0,601} \\
\hline Cukup & 49 & 45,0 & 60 & 55,0 & 109 & 100 & \\
\hline
\end{tabular}

Hubungan Konsumsi Fast Food dengan Status Gizi

Hasil dari penelitian ini menunjukkan tidak ada hubungan konsumsi fast food dengan status gizi. Subjek yang mengonsumsi fast food dengan frekuensi sering $44 \%$ yang mengalami status gizi lebih, sedangkan subjek yang mengonsumsi fast food dengan frekuensi jarang ada $40 \%$ yang mengalami status gizi lebih. Hasil penelitian menggunakan uji chi-square diperoleh nilai $p$-value sebesar 0,709 . Hal ini menunjukkan bahwa tidak ada hubungan yang bermakna antara konsumsi fast food dengan status gizi anak sekolah. Penelitian ini berbanding terbalik dengan penelitian yang dilakukan oleh Allo, et al. (2013) yang menyatakan konsumsi fast food memiliki hubungan dengan status gizi berlebih pada anak sekolah. Perbedaan hasil pada penelitian ini dapat disebabkan oleh jenis fast food yang dikonsumsi.

\section{Hubungan Minuman Berkalori dengan Status Gizi}

Pada Tabel 2 dapat dilihat hasil penelitian ini menunjukkan bahwa subjek yang mengonsumsi minuman berkalori dengan frekuensi sering 43,2\% mengalami gizi lebih, tidak jauh berbeda dengan subjek yang mengonsumsi minuman berkalori dengan frekuensi jarang $43,9 \%$ yang mengalami status gizi 
lebih. Berdasarkan hasil uji chi-square menunjukkan nilai p-value 0,936, maka tidak ada hubungan yang bermakna antara konsumsi minuman berkalori dengan status gizi anak sekolah ( $p$ $>0,05)$. Penelitian ini sejalan dengan penelitian yang dilakukan oleh Akhriani, et al. (2014) yang menyatakan bahwa asupan minuman berkalori tidak memiliki hubungan yang signifikan terhadap status gizi anak sekolah.

\section{Hubungan Asupan dengan Status Gizi}

Tidak ada hubungan antara asupan energi dengan status gizi pada subjek penelitian ini. Tabel 2 menunjukkan bahwa tidak terdapat hubungan yang signifikan yang ditandai dengan p-value 0,101. Subjek yang memiliki asupan energi lebih 64,3\% mengalami gizi lebih, sedangkan yang memiliki asupan energi cukup 41,6\% yang mengalami gizi lebih. Berbeda dengan penelitian yang dilakukan oleh Yulni, et al. (2013) terdapat hubungan antara asupan energi dengan status gizi anak sekolah.

Hasil penelitian ini menunjukkan bahwa sebesar $32,1 \%$ subjek yang memiliki status gizi lebih memiliki asupan karbohidrat berlebih. Berdasarkan hasil uji chi-square menunjukkan nilai p-value 0,004, maka ada hubungan yang bermakna antara asupan karbohidrat dengan status gizi anak sekolah. Yulni, et al. (2013) juga menyatakan bahwa asupan karbohidrat berbanding lurus dengan status gizi anak sekolah.

Proporsi subjek status gizi lebih dengan asupan protein lebih, lebih banyak $(22,6 \%)$ daripada subjek dengan status gizi lebih dengan asupan protein cukup $(47,9 \%)$. Berdasarkan hasil uji chisquare dengan nilai p-value 0,010 maka ada hubungan antara asupan protein dengan status gizi anak sekolah.

Penelitian ini menunjukkan hubungan asupan lemak dengan status gizi. Proporsi subjek yang mengalami status gizi lebih dengan asupan lemak lebih, lebih rendah $(40,9 \%)$ daripada subjek dengan status gizi lebih dengan asupan lemak cukup (45,0\%). Berdasarkan hasil chi-square dengan nilai p-value 0,601 maka, tidak ada hubungan antara asupan lemak dengan status gizi anak sekolah. Hal serupa terjadi pada penelitian Mardatillah (2008) menyatakan hasil uji statistik $p$-value 0,461 maka, tidak ada hubungan antara asupan lemak dengan status gizi lebih.

\section{DISKUSI}

Status zat gizi dapat dipengaruhi oleh berbagai faktor, seperti asupan zat gizi, pola konsumsi, aktivitas fisik dan sebagainya. Pola konsumi yang tidak baik dapat berpengaruh kepada status gizi baik gizi lebih maupun gizi kurang. Fast food dan minuman berkalori yang saat ini marak dikonsumsi memiliki sumbangsih terhadap permasalahan gizi. Fast food merupakan makanan yang dapat diolah dan dihidangkan atau 
disajikan dengan cepat oleh pengusaha jasa boga, rumah makan, restoran. Fast food diartikan sebagai makanan tinggi garam dan lemak serta rendah serat (Kemenkes, 2013). Hasil uji pada penelitian ini menggunakan uji chi-square diperoleh tidak ada hubungan yang bermakna antara konsumsi fast food dengan status gizi anak sekolah.

Tidak terdapat hubungan bermakna antara konsumsi fast food dengan status gizi ada penelitian Emirza (2012), walaupun subjek dengan status gizi lebih yang sering mengonsumsi fast food lebih tinggi $(55,3 \%)$ daripada subjek yang jarang mengonsumsi fast food $(51,7 \%)$. Penelitian lain yang dilakukan Kristiani, et al. (2009) mengatakan tidak ada hubungan antara frekuensi konsumsi dengan status gizi dikarenakan banyak faktor-faktor lain yang memengaruhi status gizi antara lain penyakit infeksi, ketersediaan pangan, pendidikan, pengetahuan gizi, dan aktivitas fisik.

Minuman berkalori adalah minuman yang tidak mengandung alkohol, merupakan minuman olahan dalam bentuk bubuk atau cair yang mengandung bahan makanan atau bahan tambahan lainnya baik alami maupun sintetik yang dikemas dalam kemasan siap untuk dikonsumsi. Minuman berkalori terdiri atas dua jenis, yaitu minuman berkalori dengan berkarbonasi dan minuman berkalori tidak berkarbonasi. Hasil uji pada penelitian ini menggunakan uji chi-square diperoleh tidak ada hubungan yang bermakna antara minuman berkalori dengan status gizi anak sekolah. Berdasarkan hasil FFQ, jenis minuman berkalori yang sering dikonsumsi pada penelitian ini yaitu lechy tea, teh kemasan, soft drink.

Namun tidak semua subjek dalam penelitian ini mengonsumsi minuman berkalori dikarenakan mendapatkan edukasi dari keluarga responden. Hal ini juga terjadi pada penelitian yang dilakukan Safriani (2014) yang mengatakan tidak terdapat hubungan signifikan antara frekuensi minuman berkalori dengan status gizi. Hal ini dikarenakan konsumsi minuman berkalori tidak berpengaruh secara langsung terhadap status gizi. Jika konsumsi minuman berkalori masih di bawah jumlah kebutuhan energi, tidak akan menyebabkan kegemukan.

Asupan energi digunakan untuk pertumbuhan, metabolisme dalam pemanfaatan bahan makanan, dan aktivitas fisik. Kurangnya asupan energi kebutuhan gizi seseorang akan menyebabkan kekurangan gizi. Hasil uji chi-square diperoleh tidak ada hubungan yang bermakna antara asupan energi dengan status gizi anak sekolah. Berdasarkan hasil recall pada penelitian ini, asupan energi tidak berhubungan dengan status gizi lebih yaitu banyaknya subjek yang memiliki tingkat asupan energi kurang dari yang dibutuhkan oleh tubuh, kurangnya variasi makanan, dan frekuensi makan subjek dan sebagian besar subjek mengonsumsi makanan yang hampir sama dalam satu hari. 
Hal ini juga terjadi pada penelitian Manuhutu, et al. (2017), yang menyatakan tidak ada pengaruh secara statistik antara tingkat konsumsi energi dengan status gizi anak sekolah. Hal ini disebabkan ketidakmampuan tubuh mengabsorpsi zat-zat gizi yang masuk ke dalam tubuh dan adanya gangguan pencernaan. Kekurangan energi dapat berakibat pada kurang berat badan dari berat seharusnya. Pada anak usia sekolah, kekurangan energi dapat menghambat pertumbuhan.

Karbohidrat memegang peranan penting dalam makanan karena merupakan sumber energi utama. Produk yang dihasilkan terutama dalam bentuk gula sederhana yang mudah larut dalam air dan mudah dibawa ke seluruh sel-sel guna penyediaan energi (Almatsier, 2009). Hasil uji chi-square diperoleh ada hubungan yang bermakna antara asupan energi dengan status gizi anak sekolah. Diperoleh nilai $\mathrm{PR}=2,463$ yang dapat disimpulkan bahwa subjek dengan asupan karbohidrat lebih memiliki risiko lebih sebesar 2,463 kali untuk memiliki status gizi lebih dibandingkan dengan subjek yang memiliki asupan karbohidrat kurang.

Hal ini dikarenakan keragaman makanan sumber karbohidrat dari subjek yang bervariasi yang dilihat dari recall 2 x 24 jam tidak berturut - turut. Hal ini sejalan dengan penelitian Yulni, dkk (2013) dengan nilai p-value 0,011 yang menunjukkan bahwa terdapat hubungan signifikan antara asupan karbohidrat dengan status gizi.
Protein berfungsi untuk pertumbuhan, pembuat hormon, dan enzim yang penting bagi metabolisme tubuh dan sumber energi ketika asupan karbohidrat tidak memenuhi kebutuhan. Menurut Soediaoetama (2008), kekurangan protein dapat menyebabkan anak terserang infeksi yang dapat meningkatkan morbiditas dan mortalitas pada anak. Selain itu, tinggi badan, berat badan, dan pertumbuhan organ maupun jaringan lainnya akan terganggu jika asupan protein dalam makanan seharihari tidak terpenuhi. Hasil uji chi-square diperoleh ada hubungan antara asupan protein dengan status gizi. Diperoleh nilai $\mathrm{PR}=3,154$ yang diartikan subjek dengan asupan protein lebih memiliki risiko sebesar 3,154 kali lebih besar untuk memiliki status gizi lebih dibandingkan dengan subjek yang memiliki asupan protein kurang.

Hal ini diperkirakan karena asupan protein yang dirata-ratakan pada hari libur dan hari sekolah pada hasil recall 2x24 jam. Adanya hubungan antara asupan protein dengan status gizi lebih dikarenakan sebagian subjek lebih sering mengonsumsi sumber protein hewani daripada sumber protein nabati sehingga sumber makanan yang dikonsumsi subjek kurang bervariasi.

Di dalam tubuh lemak berfungsi terutama sebagai cadangan energi dalam bentuk jaringan lemak yang ditimbun di bagian-bagian tubuh tertentu di bawah kulit (Sediaoetama, 2008). Hasil uji chisquare diperoleh tidak ada hubungan antara asupan lemak dengan status gizi 
anak sekolah. Tidak ada hubungan antara asupan lemak dengan status gizi pada subjek dikarenakan gambaran cara memasak sumber makanan dengan cara ditumis dan digoreng berdasarkan hasil recall 2 × 24 jam tidak berturut-turut. Tingginya proporsi subjek dengan konsumsi lemak lebih menunjukkan bahwa menu makanan yang dimakan oleh subjek merupakan makanan tinggi lemak khususnya lemak hewani.

\section{RUJUKAN}

Akhriani, M., et al. (2014). Hubungan minuman berpemanis dengan kejadian kegemukan pada remaja di SMP Negri 1 Bandung. Indonesian Journal of Human Nutrition. 3(1): 29-40.

Almatsier, S. (2009). Prinsip Dasar Ilmu Gizi. Jakarta: PT Gramedia Pustaka Utama.

Allo, B., et al. (2013). "Hubungan antara pengetahuan dan kebiasaan konsumsi fast food dengan kejadian gizi lebih pada siswa Sekolah Dasar Negeri Sudirman I Makassar". 02 Desember 2018.http:/ / repository.unhas.ac.id/b itstream/handle/123456789/5547/JU RNAL.pdf?sequence $=1$

Anzarkusuma, et al. (2014). Status gizi berdasarkan pola makan anak Sekolah Dasar Rajeg Tangerang. Journal of Human Nutrition, 1(2): 135148.

Badan Penelitian dan Pengembangan Kesehatan. (2013). Riset Kesehatan Dasar $\quad$ (RISKESDAS) 2013.
Kementerian Kesehatan Republik Indonesia.

Bowman, AS. \& Bryan, TV. (2004). Fast food consumption of U.S adults: Impact on energy and nutrient intakes and overweight status. Journal of the American College of Nutrition, 23(2): 168.

Bryant, et al. (2004). Nutrients for cognitive development in school age children. Nutrition Review, 62(8): 295-306.

Edelstein \& Sharlin, Kristianto Yohanes dkk (penerjemah). (2015). Buku Ajar Gizi Dalam Kehidupan. Jakarta: Buku Kedoktoran EGC.

Emirza, P. (2012). Hubungan Asupan Makanan dan Faktor Lainnya Terhadap Kejadian Kelebihan Berat Badan pada Remaja Berumur 10-12 Tahun di SD Islam Harapan Ibu tahun 2012. Skripsi. Depok. Universitas Indonesia.

Mahan, LK \& Escott-Stump, S. 2012. Krause's Food and Nutrition Therapy 13th edition. Philadelphia: Saunders Elsevier.

Mardatillah. 2008. Hubungan Konsumsi Makanan Siap Saji Modern (Fastfood), Aktifitas Fisik dan Faktor Lainnya dengan Kejadian Gizi Lebih pada Remaja SMA Islam P.B. Soedirman. Skripsi. Jakarta. Universitas Indonesia. 
Puspasari, N. \& Andriani, M. (2017). Hubungan pengetahuan ibu tentang gizi dan asupan makan balita dengan status gizi balita $(\mathrm{BB} / \mathrm{U})$ usia 12-24 bulan. Amerta Nutrition, 1(4): 369-378.

Rahmawati, T. \& Marfuah, D. (2016). Gambaran status gizi pada anak sekolah dasar. Profesi, 14(1): 72-76.

Safriani, F. (2014). Faktor-Faktor yang Berhubungan dengan Perilaku Konsumsi Minuman Ringan (Soft Drink) pada Siswa SMA di Bogor. Skripsi. Bogor. Institut Pertanian Bogor.

Soediaoetama, AD. (2008). Ilmu Gizi Untuk Mahasiswa dan Profesi. Jilid 1. Jakarta: Dian Rakyat.

Supariasa, IDN., et al. (2002). Penilaian Status gizi. Jakarta: Buku Kedokteran EGC.

Yulni, et al. (2013). Hubungan asupan gizi makro dengan status gizi pada anak sekolah dasar di wilayah pesisir Kota Makassar tahun 2013. Media Kesehatan Masyarakat Indonesia, 9(4): 205-221. 